\title{
Granting Birthright Citizenship - A Door Opener for Immigrant Children's Educational Participation and Success?
}

\author{
Christina Felfe \\ Judith Saurer
}

CESIFO WORKING PAPER NO. 4959

CATEGORY 5: ECONOMICS OF EDUCATION

SEPTEMBER 2014
An electronic version of the paper may be downloaded
- from the SSRN website:
- from the RePEc website:
- from the CESifo website:
WWW.SSRN.com
www.RePEc.org
www.CESifo-group.org/wp

\section{CESifo}




\title{
Granting Birthright Citizenship - A Door Opener for Immigrant Children's Educational Participation and Success?
}

\begin{abstract}
Does granting birthright citizenship help immigrant children integrating in the host country's educational system? We address this question using a reform of the German naturalization law in 1999 that entitled children born after January 1, 2000 with birthright citizenship. We use a difference-in-difference design that compares children born shortly before and after the cut-off in years of policy change and years where no policy change took place. Our empirical analysis relies on administrative data from school entrance examinations and on the German Micro Census. We find positive effects on immigrant children's educational participation, both in non-mandatory preschool and upper secondary school. In addition, birthright citizenship enhances children's socio-behavioral development.
\end{abstract}

JEL-Code: I210, K370.

Christina Felfe

University of St. Gallen

Varnbüelstr. 14

Switzerland - 9000 St. Gallen

christina.felfe@unisg.ch
Judith Saurer

Ifo Institute - Leibniz Institute for

Economic Research

at the University of Munich

Poschingerstr. 5

Germany-81679 Munich

saurer@ifo.de

September 16, 2014 


\section{Introduction}

The integration of immigrants constitutes a remarkable challenge for many developed countries. Economic disadvantages, such as worse job prospects or lower earnings, are only some of the problems immigrants have to deal with. ${ }^{1}$ Disadvantages also exist among the descendants of immigrants and are, for instance, evident in form of lower educational achievements. ${ }^{2}$ Closing such gaps between the immigrant and native population may matter for several reasons. The lack of educational and economic success may lead to social and economic exclusion, which in turn may lead to social unrest. In addition, poor performance in the educational system or on the labor market may foment prejudices of the native population towards the immigrant population and thus, hamper the integration of immigrants.

Granting citizenship is one highly debated policy meant to foster the integration of immigrants. Expected benefits are above all related to immigrants' conditions on the labor market (Chiswick, 1978; Brantsberg, Ragan, \& Nasir, 2002; Fougère \& Safi, 2009; Steinhardt, 2012; Gathmann \& Keller, 2014). Besides the prerequisites for the acquisition of citizenship, many countries are debating the introduction of birthright citizenship for immigrant children (e.g. Germany in 2000, Portugal in 2004, Greece in 2010, Austria and Italy in 2013). In contrast, the U.S. are considering the abolishment of birthright citizenship in light of rising birth rates among illegal immigrants. Yet, what are the consequences of granting immigrant children citizenship at birth? Several recent studies document positive effects on the integration efforts of immigrant children's parents. In particular, they find reduced remittances, a lower probability of return migration as well as increased interactions with the local community and usage of the local language (Avitable, Clots-Figueras, \& Masella, in press-a, in press-b; Piracha \& Zhu, 2012; Sajons, 2010, 2012). The direct consequences of birthright citizenship on the children, however, are basically unstudied. ${ }^{3}$

To the best of our knowledge, we are the first to address the consequences of granting birthright citizenship on children's educational outcomes from

\footnotetext{
${ }^{1}$ For a description of the economic situation of first- and second-generation immigrants in Europe and the U.S. please refer to Algan, Dustmann, Glitz, and Manning (2010); Borjas (1985); Chiswick (1980)

${ }^{2} \mathrm{~A}$ comparison of the educational attainment of second-generation immigrants and children born to native parents is provided, for instance, by Dustmann, Frattini, and Lanzara (2012); Riphahn (2003).

${ }^{3}$ The exception is Avitable et al. (in press-a) who analyze whether birthright citizenship affects fertility - as a measure of the quantity of children - and children's health - as a measure of the quality of children.
} 
birth to adolescence. ${ }^{4}$ Our particular focus lies on the participation and progress of immigrant children in the host country's educational system.

Analyzing the consequences of birthright citizenship on children's educational outcomes is challenging as mainly families who feel part of the host country's society and/or see themselves living in the host country in the long-run apply for citizenship. A mere comparison between immigrant children with and without citizenship is thus prone to yield biased results. Our identification strategy therefore relies on a natural experiment - a reform of the naturalization law in Germany that implied a change from "ius sanguini" - only descendants of home country nationals receive citizenship - to "ius soli" - everyone born on the national territory is eligible for citizenship. ${ }^{5}$ To be more precise, the reform under study established that all immigrant children born in Germany after January 1, 2000, with at least one parent exhibiting a minimum duration of residence of eight years, were automatically granted German citizenship. ${ }^{6}$ This setup provides us with a sharp cut-off regarding the entitlement to birthright citizenship. To abstract from possible seasonal effects or age of school entry effects on children's educational outcomes, we do not only compare immigrant children born shortly before and after the cut-off date (second semester of 1999 and first semester of 2000, respectively), but draw upon immigrant children from earlier and later school cohorts as a control group (second semester of 1998 or 2000 and first semester of 1999 or 2001, respectively). In other words, we employ a

\footnotetext{
${ }^{4}$ As we have recently learned, there is simultaneous work by Irma Clots-Figueras and Christoph Sajons. They, however, rely on an alternative dataset the National Education Panel Study (NEPS) which is not only much smaller in size, but also contains only one cohort appropriate for the analysis of the impact of the reform under study. The differences to our study are thus as follows: First, the data we use, administrative data from school entrance examinations and the German Micro Census, provides information on childrens educational outcomes from birth up to the time when children are tracked into upper secondary school. Clots-Figueras and Sajons, on the contrary, study only one of our outcome variables, namely tracking into upper secondary school. Second, our data is available for several school cohorts. To be more precise, we rely on children born between July 1998 and June 2001. Thus, our identification strategy relies on a comparison of immigrant children born before and after the cut-off date in years of policy change and years where no policy change took place and not on a comparison of immigrant and native children.

${ }^{5}$ The above cited studies by Avitable et al. (in press-a), Avitable et al. (in press-b), Piracha and Zhu (2012), Sajons (2010), and Sajons (2012) rely on the same reform to study the impact of birthright citizenship on parental outcomes.

${ }^{6}$ The reform changed additional features of the naturalization law, among others it reduced the period of residence required for eligibility for adults' citizenship from 15 to eight years and it established a transition rule regarding citizenship rights for all children born between 1990 and 1999. For details on the reform please refer to Section 2.1.
} 
difference-in-difference design (DiD) to isolate the causal effect of introducing birthright citizenship on the educational attainment of children.

We draw upon two large and unique datasets, which enables us to yield precise results despite the fact that our empirical analysis focuses on a very small subset of the German population - immigrant children of only a few cohorts. First, we use administrative records from school entry examinations of all children born in one German federal state (Schleswig-Holstein). These records contain physicians' assessments of children's school readiness at age six based on a set of cognitive and non-cognitive skills (among others language and socio-behavioral skills). An accompanying questionnaire, filled out by the parents, provides additional information on children's preschool attendance and important background characteristics. We use the records of 6,752 immigrant children, born between July 1998 and June 2001 and examined for school entry in 2005, 2006 and 2007. Second, we use the German Micro Census, Europe's largest household survey. This dataset - available for the whole federal republic of Germany - provides us with educational outcomes at a later stage of childhood, namely tracking into different types of secondary school at age ten. We use the survey years 2010, 2011 and 2012 and thus a sample of 2,595 immigrant children born between July 1998 and June 2001.

Our results suggest an overall positive impact of birthright citizenship on the participation of immigrant children in the German educational system. Introducing birthright citizenship increases non-mandatory preschool attendance by 3.2 percentage points (ppt) and access to upper secondary school by 7.3 ppt. Do we also observe positive effects on children's skill development which may in part explain the improved access to upper secondary school? At the time of primary school entrance, we indeed find positive effects on children's conduct (1.9 ppt) and emotional stability (2.2 ppt). Results also point towards gains in German language proficiency (3.4 ppt), but this result is very imprecise since only very few children participated in the language tests. Our results are robust to a variety of sensitivity checks, such as introducing one further control group - native children - and narrowing the window around the cut-off date.

Finding positive effects of birthright citizenship on the educational participation and success of immigrant children in the host country's educational system raises the question about the underlying channels. Why should birthright citizenship enhance the integration of immigrant children? First, citizenship is a premise for political and professional equality and thus for successful integration in the host country in the long-run. As a result, it is likely to enhance children's future labor market opportunities and thus to 
increase their family's likelihood to stay in the host country. Immigrant parents may therefore decide to invest into their children's host country-specific human capital by, for instance, increasing their usage of the local language, developing a network of native friends, or adopting cultural habits (Avitable et al., in press-b; Sajons, 2012). Second, citizenship may reduce discrimination by peers or local decision makers (e.g., teachers or school principals). We discuss these channels in detail in Section 2.3.

The remainder of the paper is structured as follows. The next section provides a brief overview of the institutional background and discusses the main mechanisms through which birthright citizenship may exert its effects on children's educational outcomes. Section 3 introduces the empirical strategy. Section 4 describes the different data sets used for our analysis. Section 5 presents our main results and provides a series of robustness checks. Section 6 concludes.

\section{Background}

\subsection{The Reform of the Nationality Law in 1999}

After a long and heated debate how to deal with the rising numbers of immigrants, in May 1999 the German parliament decided to undertake a major revision of the "German Citizenship and Nationality Law" dating back to 1913. On July 15, 1999 the German parliament ratified the new version of the law. ${ }^{7}$ The reform implied the following aspects: first, it introduced birthright citizenship; second, it changed the eligibility criteria for naturalization; and third, it forbade dual citizenship (beyond the age of 23 years).

The focus of our paper lies on the first aspect of the reform. Until 1999, citizenship was granted according to the "ius sanguinis". In other words, children could only receive German citizenship if at least one parent was German citizen. As of January 1, 2000, the prevailing regime changed to "ius soli", which granted each child born on German territory a conditional right to German citizenship at birth together with the parent's citizenship. The condition for birthright citizenship was that at least one parent had a permanent residence permit in Germany for eight or more years. If this condition was fulfilled, German citizenship was automatically recorded in the register of birth without the parents applying for it. Children could then

\footnotetext{
${ }^{7}$ The legal text can be found in StAG 4 Abs. (3) (Bundesministerium der Justiz und für Verbraucherschutz, 1999).
} 
enjoy dual citizenship up to the age of 23 years, afterwards they needed to decide between the two nationalities. Parents of children born between 1991 and 1999 could retrospectively apply for their children's citizenship within a transition period (January 1 - December 31, 2000). Yet, in practice only very few people made use of this transition rule.

The reform also changed the general eligibility criteria for citizenship. On the one hand, it relaxed the eligibility requirement on the length of residence from 15 down to eight years. On the other hand, it tightened the eligibility requirements in a way that applicants needed to express their loyalty to the German constitution, to be financially independent (i.e. they must not receive social security or unemployment benefits), to prove a clean criminal record, to be proficient in the German language, and finally to renounce their former citizenship. Thus, while immigrants had to wait fewer years to apply for German citizenship, the required effort and the costs to do so increased substantially.

What did the reform imply for the costs of receiving/applying for German citizenship at birth? Children born after the cut-off date were granted citizenship automatically at birth without their parents doing anything. In contrast, children born before the cut-off date could only be granted citizenship in case their parents applied for German citizenship (with the exception of the one year transition period where parents could apply for their children's citizenship independently of their own citizenship). In other words, the reform of the German naturalization law reduced the costs of endowing children with German citizenship dramatically: in the case of children born after the cut-off date, application for citizenship was for free; in the case of children born before the cut-off date, application for citizenship came along with administrative costs and the renunciation of parents' original citizenship.

\subsection{The Education System in Germany}

The German education system is threefold: i) first years between birth and primary school, which are divided into early care available for children age zero to two and Kindergarten available for children age three to six; ii) primary school, which starts usually at age six and covers the first four years of schooling; iii) secondary schooling which starts at age ten or eleven and covers between five (mandatory) and nine further years.

Preschool attendance is non-mandatory in Germany. Yet, since 1996 every child turning three years old is entitled to a legal claim on a place in Kindergarten. As a result, in the late 1990s supply of Kindergarten slots rose 
dramatically to essentially meet demand in the early 2000s. Slots are heavily subsidized and fees are not only deductible from personal income taxes, but also progressive in family income. In case of severe financial constraints, fees are even reimbursed by the local youth welfare service (Bundesministerium für Familie, Senioren, Frauen und Jugend, 2013). In 201289 \% of all threeyear old children and $96 \%$ of all five-year old children attended preschool (Federal Statistical Office, 2012). Among three- to five-year old immigrant children, this share only amounted to $85 \%$ (Bildungsberichterstattung, 2012). One goal of the German government is to raise participation of immigrant children, in particular given their high gains from attending preschool, for instance, in terms of language proficiency, school readiness and referral to upper secondary school (B. Becker, 2006; R. Becker \& Tremel, 2011; Dustmann, Raute, \& Schönberg, 2013).

Between birth and primary school, children have to undergo several mandatory medical screenings. These medical screenings are meant to document children's health, diagnose medical anomalies, and provide necessary treatment as early as possible. An important medical screening is the school entrance examination (SEE). A pediatrician employed by the local health service examines every child in the year prior to entering primary school in the context of the SEE. Besides documenting a child's health, the focus of this examination is to determine whether a child is "ready" to follow the school curriculum or not. The school readiness diagnosis is an important piece of information regarding school enrollment but it is not binding. It is ultimately up to the parents to decide whether to enroll their child in school or not. In case of a negative school readiness diagnosis children usually receive special education which is provided either by the primary school teacher during mandatory school hours or by a remedial teacher after mandatory school hours.

In the context of the SEE, pediatricians assess several skill dimensions, among others language skills and socio-behavioral development. A typical assessment of childrens language skills contains language exercises such as describing a picture story and repeating several pseudo words or sentences. Recently, local health services have moved on to test nonnative children with respect to their proficiency in the German language. The assessment of children's socio-behavioral development is based on physicians observations as well as on a questionnaire designed to identify emotional instability, conduct problems, social behavior and peer relationships given to the accompanying caregiver Goodman (1997).

Once having passed all four grades in primary school, students are referred to secondary school. At that point - usually at age ten or latest 
eleven - students are tracked into one of the following three school types: ${ }^{8}$ lower secondary school - the so-called Hauptschule; intermediate secondary school - the so-called Realschule; and upper secondary school - the so-called Gymnasium. Lower secondary school lasts until grade nine or ten, endows students with a general education and prepares them for an apprenticeship; intermediate secondary school lasts until grade ten and can either lead to an apprenticeship or to a higher vocational school; upper secondary school which is also considered as the academic track, lasts until grade twelve or 13 and prepares students for university.

Primary school teachers give recommendations for tracking a child into one of the three types of secondary school. Recommendations should be based on a child's personality and performance shown during primary school, but not on a child's socio-economic or demographic background. Depending on the federal state, these recommendations may be binding or not (Ständigen Konferenz der Kultusminister der Länder in der Bundesrepublik Deutschland, 2010). Only in five German States the decision on further education lies completely in the hands of the parents. Those states are Bremen, Hamburg, Hessen, Mecklenburg-Vorpommern, and Niedersachsen. In all other states such recommendations are either binding or children have to fulfill extra exams or a probationary year. In 2009, $24.1 \%$ of all 15-year-old immigrant children attended lower secondary school, in comparison to 13.3 $\%$ of their native peers. In contrast, $25.9 \%$ of all 15-year-old immigrant students attended upper secondary school while $37.1 \%$ of their native peers did so (Bildungsberichterstattung, 2012). This difference might be the result of worse performance during elementary school, but also of possible discrimination by teachers - i.e. criteria not related to immigrant children's skills or school performance (Lüdemann \& Schwerdt, 2013). Given important consequences of tracking for later success in life, one goal should be to minimize this gap in early tracking or at least allow for ample opportunities to revise initial track assignment (Duflo, Dupas, \& Kremer, 2011; Dustmann, 2004; Dustmann, Puhani, \& Schönberg, 2014).

\subsection{The link between birthright citizenship and children's education}

Why should citizenship at birth exert any effect on children's educational development? In what follows we describe a simple model of children's human

\footnotetext{
${ }^{8}$ There exist also a number of alternative school forms such as the Waldorfschule and the comprehensive school (Gesamtschule). Overall, the number of these alternative school forms is negligible.
} 
capital production which helps discussing the main mechanisms underlying any effect of granting birthright citizenship on children's human capital production. Figure 1 illustrates this model.

Figure 1: Birthright Citizenship and Human Capital Production Function

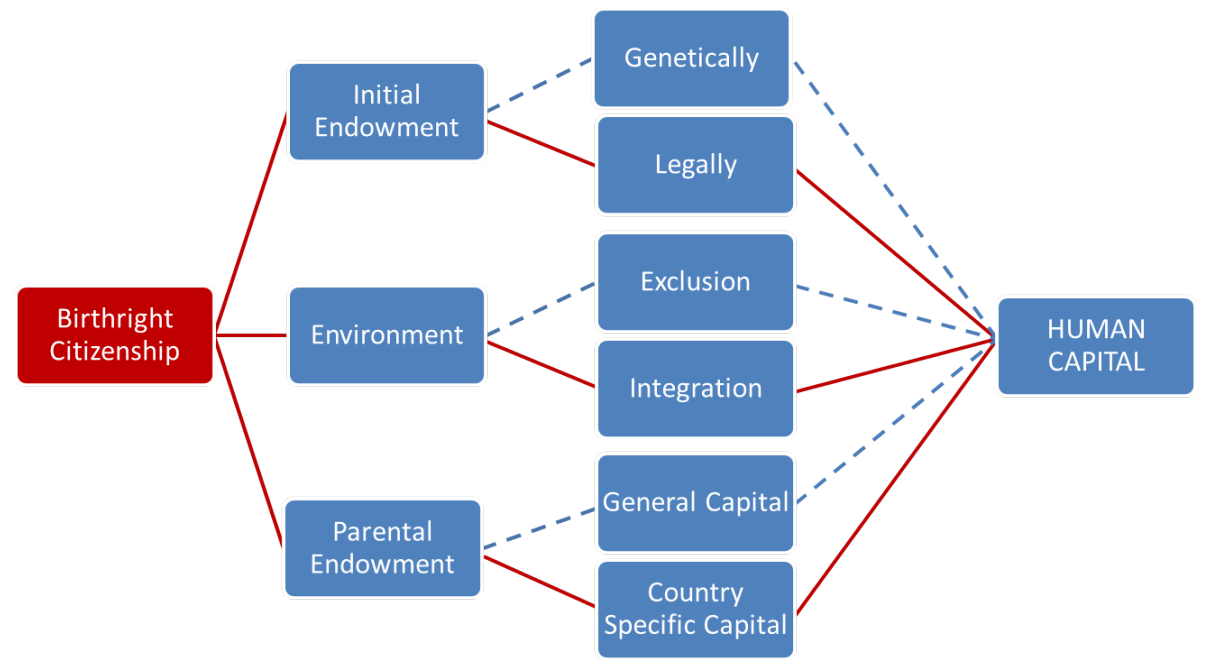

The human capital production theory talks about three major input factors (see Cunha and Heckman (2007)): children's initial endowment, which refers on the one hand to children's genetic pool, but on the other hand to children's legal standing; children's environment, which refers to any experiences of the child in the social (e.g., neighborhood or friends) or institutional environment (e.g., peers and teachers in school); parents' investments, which can be of monetary and non-monetary nature (e.g., time). Where does a change in the naturalization law enter the human capital production function? First, being granted citizenship from birth onwards constitutes a positive shock to children's initial endowment. Citizenship improves a child's legal position by allowing for political participation and thus improving a child later standing in the society. Second, citizenship might also influence the behavior of peers or teachers towards the child, i.e. a child might be less bullied or discriminated against. Finally and most importantly, having the prospect of being German citizen might influence parents' investment into the human capital of their children. In turn we discuss why this should be the case.

On the one hand, human capital might be general, and hence valuable independently of the country of residence. For instance, basic skills, such 
as being able to speak or to walk, as well as more advanced skills, such as being able to socially interact or to perform some mathematical tasks, are valuable across country boarders. On the other hand, human capital might also be country specific and hence loose its value once changing the country of residence. Examples for such country specific human capital are the local language or country specific norms and culture. Thus, immigrant parents face the challenge that the human capital investments they endow their children with might not only differ from the human capital investments native parents endow their children with, but also be partially worthless outside their country of origin.

The willingness of immigrants to invest into their children's host country specific human capital is likely to depend on the expected return. Returns to host country specific human capital rise with the expected length of stay in the host country. Birthright citizenship improves children's legal standing and thus their integration into the host countrys society, both socially by reducing prejudices and economically by giving them access to a wider range of jobs. As a result, immigrant families are more likely to project their future in the host country and thus to not only integrate better into the host country, but also to invest into their childrens host country specific human capital. There are several recent papers providing supportive evidence for the impact of children's citizenship on parents' intentions to stay in host country and integration efforts. Notice, that these papers study the same reform as we do, but mostly rely on the German Socio-Economic Panel a dataset which is much smaller, but richer in background characteristics than the datasets we use. Sajons (2010) finds direct evidence in favor of birthright citizenship representing a positive shock to children's expected length of stay: he finds a reduction in return migration among parents of children, who were granted birthright citizenship. Piracha and Zhu (2012) find a reduction in remittances, which is another piece of evidence in favor of a prolonged stay in the host country. Avitable et al. (in press-b) and Sajons (2012) provide evidence that the introduction of birthright citizenship increases parents' integration efforts: they both find that parents interact more with the local community and use more often the German language once their children enjoy birthright citizenship. Given this evidence, we expect a positive impact of birthright citizenship on immigrant children's participation in the host country's educational system as well as their skill development. 


\section{Empirical Approach}

Analyzing the impact of citizenship on children's development is challenging as parents applying for citizenship may differ from parents not applying for citizenship in their willingness to integrate and to stay in the host country. To overcome this endogeneity issue we rely on the reform of the German naturalization law in 1999. As described in Section 2.1 immigrant children born after January 1, 2000 were granted German citizenship at birth conditional on at least one of their parents having had a permanent residence permit in Germany for eight or more years. This cut-off regarding the eligibility for citizenship at birth constitutes the core of our identification strategy.

To be more precise, we compare children born shortly before the cut-off to children born shortly after the cut-off. ${ }^{9}$ To abstract from any differences across school cohorts, we restrict our sample to one school cohort and thus children born six months before and after the cut-off date (second semester of 1999 and first semester of 2000, respectively). To abstract further from any seasonal effects in children's educational outcomes (Buckles \& Hungerman, 2013), we do not only compare children born shortly before and after the cut-off date, but draw upon children from earlier and later school cohorts as control groups (in particular, from the second semester of 1998 and 2000, and the first semester of 1999 or 2001). In other words, we employ a difference-in-difference design (DiD) that compares outcomes of children born shortly before and after the cut-off date in the year of policy change and adjacent years where no policy change took place. ${ }^{10}$ Thus, the equation to be estimated looks as follows:

\footnotetext{
${ }^{9}$ Ideally we would like to restrict our sample further to children whose parents have resided for at least eight years in Germany. Unfortunately, the SEE data does not contain information on the length of residence. We therefore abstain from this sample restriction in our baseline analysis. When analyzing immigrant childrens tracking into upper secondary school which is based on the GMC, we test the robustness of our results restricting the sample to immigrant children whose parents resided for at least eight years in Germany at the time of childbirth. Results are not only robust, but also bigger in size and thus suggest that all estimates based on the SEE are if anything lower bounds of the sharp estimates. Whether we would like to use children whose parents have resided for less then eight years in Germany as a control group is unclear as these families might belong to different immigration waves and thus to different ethnic groups.

${ }^{10}$ A similar strategy has been used by Lalive and Zweimüller (2009), Dustmann and Schönberg (2012), Schönberg and Ludsteck (2011) and Danzer and Lavy (2013).
} 
$Y_{i, m}^{s}=\alpha+\beta$ Treat $_{i}+\gamma$ After $_{i, m}+\delta$ After $_{i, m} *$ Treat $_{i}+\sum_{m=1}^{12} \theta_{m} D_{i, m}+\eta X_{i}+\epsilon_{i, m}$

where $Y_{i, m}^{s}$ represent the educational outcome in dimension s of child i born in month $\mathrm{m}$. Treat $i$ is a binary variable indicating whether child $\mathrm{i}$ belongs to the treatment group, in other words whether child i belongs to the school cohort 1999/2000 when the law change happened. After ${ }_{i, m}$ is a binary variable indicating if child $i$ is born between January and June.

The effect of interest is captured by the coefficient $\delta$ preceding the interaction term Afteri, $m *$ Treat $_{i}$. Yet, does this coefficient identify the causal effect of a switch from a "ius soli" to a "ius sanguinis" regime on immigrant children's educational integration? What are potentially confounding variables with the assignment variable, month of birth, and thus should be controlled for? First, we control non-parametrically for children's age. Doing so shall account for any direct age effects on children's educational progress. Children born in the first semester of the school year are on average half a year older and thus more mature when being assessed for school readiness or being tracked into upper secondary school than children born in the second semester of the school year. Thus, unconditional DiD estimates are likely to represent a lower bound of the potentially positive effect of introducing birthright citizenship. Second, as shown by Buckles and Hungerman (2013) there is a striking seasonal pattern in children's educational development with respect to the month of birth. Children born in spring do generally better in terms of their educational development than children born in winter. Underlying reasons for such seasonal effects are differences in the socio-economic status of the mother. To address this issue we control for a set of birth month dummies $\sum D_{i, m} \cdot{ }^{11}$ In further specifications we also control for proxies of families' socio-economic status captured by $X_{i}$. In particular, we control for parental education and single parenthood.

One further crucial identifying assumption is that parents could not react to the policy change. In which ways could parents react to the policy change? First, parents could delay the birth of their child such that it was born under the new policy regime. The transition rule, however, facilitated applications for citizenship also for any child born between 1991 and 1999. Thus, it did not seem worth to delay the birth of a child and risk a child's health

\footnotetext{
${ }^{11}$ Since the binary variable After $_{i, m}$ correlates perfectly with the birth months January to June, we omit not only one, but two birth month dummies. In particular, we omit January and December, as they are immediately around the cut-off date.
} 
as German citizenship could also be acquired by application for children born before the cut-off. Second, parents might have adjusted the desired number of children downwards. In fact, Avitable et al. (in press-a) show a reduction in fertility after the introduction of birthright citizenship in Germany. They argue that this reduction in the quantity of children is due to an increase in the quality of children - as discussed in section 2.3, birthright citizenship is likely to increase the returns to country-specific skills and thus the "quality" of the children. In other words, their argument is based on the quantity-quality trade off put forward by G. S. Becker and Tomes (1976). Yet, Avitable et al. (in press-a) only find an adjustment in fertility from 2001 onwards. Hence, the children included in our sample - conceived until September 1999 - are unlikely to be affected by this concern. Nevertheless, in a robustness check we restrict our sample to children who were all conceived prior to ratification of the new naturalization law (hence, children born until April 2000). Finally, the introduction of birthright citizenship made return migration less attractive (Sajons, 2010). As a result, the remaining sample might be selected, in particular, the older the children grow. The arising selection, however, is likely to lead to a lower bound of the effect as the reform might have induced less integrated families and thus more disadvantaged children to stay in Germany.

Overall, we do not see any reason to believe that the children born before and after the cut-off date differ systematically from each other in a way that could severely bias our estimates. Yet, to address the concern of any further unobserved changes in the conditions children born before and after the cutoff are exposed to, we introduce a further control group - native children and employ a triple DiD design. The exact specification is explained in Section 5.3.

\section{Data}

The question under study requests data that provides information on children's educational outcomes over the first ten years after child birth. In addition, our analysis relies on a very small subgroup of the German population: immigrant children born in a few school cohorts only $(1998 / 1999,1999 / 2000$ and 2000/01). Since there is no single dataset fulfilling both conditions, we draw upon two datasets for our empirical analysis: first, school entry examinations (SEE) from one German state, Schleswig-Holstein; ${ }^{12}$ and second,

\footnotetext{
${ }^{12}$ Unfortunately, administrative data on children's early educational outcomes are not available for the whole German territory, but for selected states only. In fact, access to
} 
the German Micro Census (GMC). The following subsections describe both datasets. Descriptives of the outcomes of both data sets can be found in the Appendix, A.1.

\subsection{School Entrance Examination Data}

The school entrance examinations (SEEs) of Schleswig-Holstein serve as a basis for our analysis on children's educational outcomes up to primary school. As described in Section 2, SEEs are mandatory for all children who turn six years between July of the previous year and June of the year of school entry. Children born between July 1998 and June 2001 are thus included in the SEEs 2005, 2006 and 2007. ${ }^{13}$ Our baseline sample of second generation immigrant children - children whose parents are both migrants (which means they are not born in Germany) - consists of 6,752 observations.

The recommendation on school readiness is a summary measure of the entire set of diagnoses that the pediatrician in charge of the SEE has performed. Recommendations are either "a child is ready for school" or "the child needs special education (either in school or additionally to school)". Our outcome measure of school readiness is thus a binary measure being one when the child is ready for school and zero otherwise. We additionally draw on the assessment of immigrant children's language proficiency and socio-behavioral development, both dimension where birthright citizenship is likely to make a difference. Language competence is exclusively tested for immigrant children. Tests were introduced in 2005 and at first only in the city of Lübeck. As a result, the sample used for analyzing children's language proficiency contains only 446 observations. Language competence is ranked between one and nine, indicating "fluent" to "no competence" in German. We recode this measure into a binary variable taking the value one if a child is fluent or makes at most small mistakes. The assessment of children's socio-behavioral development was also only gradually introduced from 2005 onwards and thus sample sizes regarding the different dimensions of children's socio-behavioral development are also slightly smaller (between 5177 and 6473 children). The diagnosis of children's socio-behavioral development is based on the pediatrician's observations as well as on a brief

the SEE is highly restricted and only possible when being invited for cooperation by the respective office in charge.

${ }^{13}$ Parents can ask their child to be examined already a year before the official SEE would have taken place. We exclude these children since they are a non-random sub-sample of younger age cohorts. Moreover, each child is only included once in the SEE as children who are not ready for school in one year undertake a special examination one year later. 
behavioral screening questionnaire designed to identify emotional problems, conduct problems, pro-social behavior and peer relations (Goodman, 1997). The questionnaire is usually filled out by the accompanying care giver. ${ }^{14}$ The diagnoses for the different dimensions of children's socio-behavioral development are "negative, no problems", "positive, but no treatment is necessary", "positive, already in treatment", "positive, treatment necessary", and "positive, problem will reduce child's performance in school". We recode all diagnoses to take the value one if there is no diagnosis of a developmental problem, i.e. if the child develops normally, and zero otherwise.

The questionnaire filled out by the accompanying caregiver contains furthermore a series of questions on the child and family background. As a result, we possess information on attendance of Kindergarten as well as on the child's age and gender, the household composition and parent's educational degree. Unfortunately, the SEEs only contain information on parent's country of origin, but not on their length of stay in Germany. Thus, we can not restrict our sample further to children whose parents have resided for at least eight years in Germany. In other words, our research design is fuzzy as it includes also children who do not benefit from the reform of the naturalization law despite being born after January 1, 2000. The resulting coefficient $\delta$ of the interaction term After $_{i, m} *$ Treat $_{i}$ in equation 1 thus corresponds to the "intention-to-treatment effect" of the reform of the German naturalization law among all second-generation immigrant children.

A mere comparison between foreign children born in the second semester of 1999 and the first semester of 2000 reveals the following differences (see Table A.1). Children born after the cut-off date are more likely to attend Kindergarten (94\% versus $92 \%$ ), but less likely to be ready for primary school $(77 \%$ versus $86 \%)$. In terms of language proficiency, children born after the cut-off date are slightly more fluent in German than children born before the cut-off date (62\% versus $61 \%$ ). The difference, however, is not significant at any conventional level. In terms of children's socio-behavioral development, differences are negligible. Yet, as already discussed in Section 3 children born after the cut-off are on average half a year younger at the time of assessment and thus any observed differences between children born before and after the cut-off date are likely to driven by the age difference.

\footnotetext{
${ }^{14}$ Thus, in contrast to the diagnosis of language the assessment of socio-emotional maturity might be affected by subjective perceptions of the care giver. Moreover, survey responses might be affected by non-response. Yet, given that the diagnosis is based on a pediatric assessment of those responses, the diagnosis is probably less affected by response bias. Also, in $93 \%$ of all cases, a medical diagnoses regarding socio-emotional maturity is available. This indicates that non-response bias is not a major concern.
} 
The empirical analysis therefore accounts for the age difference by controlling non-parametrically for children's age.

\subsection{German Micro Census}

The German Micro Census (GMC) - which includes one percent of the German population and thus is the largest household survey in Europe - serves as our database when analyzing children's referral to secondary school. Transition from primary school to secondary school takes place after grade four and thus when children are between ten and eleven years old. We therefore draw upon the GMC in 2010, 2011 and 2012. We restrict our sample to children whose parents are both migrants (which means they are not born in Germany and arrived before 2000 in Germany, to avoid any selection into Germany due to the reform) and children belonging to the school cohorts 1998/99, 1999/2000 and 2000/2001 and thus being born between July 1998 and June 2001. Due to the panel structure of the GMC we use the wave of 2010 for the first cohort, 2011 for the second and 2012 for the third. We restrict our sample furthermore to children residing in Germany, but excluding Berlin and Brandenburg, as children are there tracked after six and not four years of primary school. The resulting sample consists of 2,595 children.

The GMC contains information about all household members and thus enables us to link information on the children with information on their parents. As a result, we cannot only elicit our variable of interest - which school track children are attending -, but also background information on the children and the parents. Analogue to the SEE, we possess information on child's age and gender, household composition and parental education. Our outcome variable is binary and is equal to one if the child attends upper secondary school and zero otherwise.

How does second-generation immigrant children's attendance to upper secondary school compare to native children's attendance to upper secondary school? As expected, immigrant children are less likely to be tracked into upper secondary school than native children (26\% versus $37.2 \%)$. Immigrant children born after the cut-off date are additionally $3.7 \mathrm{ppt}$ more likely to attend upper secondary school than immigrant children born before the cutoff date (28.2 \% versus $24.5 \%$ ). The correlation between German citizenship and attendance to upper secondary school is significantly positive (9.5 ppt). Yet, whether this correlation is indeed causal can only be shown by the results of our DiD estimations presented in the following section.

In contrast to the SEE, the GMC provides not only information on the 
parents' country of origin, ${ }^{15}$ but also on the year of arrival to Germany. Thus, we can restrict our sample further to children whose parents have resided for eight or more years in Germany (at the time of childbirth) and who are thus entitled to birthright citizenship. The resulting sample - also referred to as the eligible sample - contains 1,524 children. Nevertheless, estimates based on this restricted sample are still intention-to-treatment effects only, as the transition rule allows children born before the cut-off to acquire citizenship upon their parents' application. Finally, the GMC contains information on the nationality of the child. Hence, we can inspect whether the introduction of the "ius soli" indeed led to an increase of citizenship among immigrant children born in Germany. Section 5.1 provides evidence on the actual share of children enjoying citizenship due to the reform of the German naturalization law.

\section{$5 \quad$ Results}

The following subsections present empirical evidence for the impact of granting birthright citizenship on the actual increase in citizenship (Section 5.1) and then on the impact of granting birthright citizenship on second-generation immigrant children's educational outcomes (Section 5.2). Section 5.3 discusses then the robustness of our results.

\subsection{The increase in citizenship at birth}

How many children actually benefitted from the introduction of birthright citizenship? Figure 2 displays the increase in citizenship among eligible children - immigrant children whose parents had resided for at least eight years in Germany at the time of childbirth. Among children born prior to the cut-off date already $67.4 \%$ possessed German citizenship. Notice, that this implies that at least one of their parents had applied for citizenship and thus given up German citizenship. Among children born after the cutoff date, the share of children being German citizens jumped up to 91.4 $\%$. The reason why the share of children possessing German citizenship does not equal to $100 \%$ is that children are allowed to possess of more than one nationality up to their 23rd birthday. When being asked to report the nationality of their child, they, however, may not report both nationalities,

\footnotetext{
${ }^{15}$ Regarding the country of origin, we can find no substantial differences neither across cohorts nor between children born before and after the cut-off date. The percentages of children with turkish roots build the largest group in all the cohorts (around $30 \%$ ).
} 
but only their own nationality. When using the sample of all immigrant children independently of their parents' length of residence in Germany our baseline sample -, the share of children being German citizens jumped from $70 \%$ to $88 \%$ (see Figure A.1 in the Appendix). Obviously, the final share of children possessing German citizenship is lower than before as not all of these children were eligible for citizenship at birth (not all of them had parents who had resided for eight or more years in Germany). The share of compliers in our baseline sample thus corresponds to $18 \%$.

Figure 2: Share of Eligible Children Enjoying Citizenship by Month of Birth

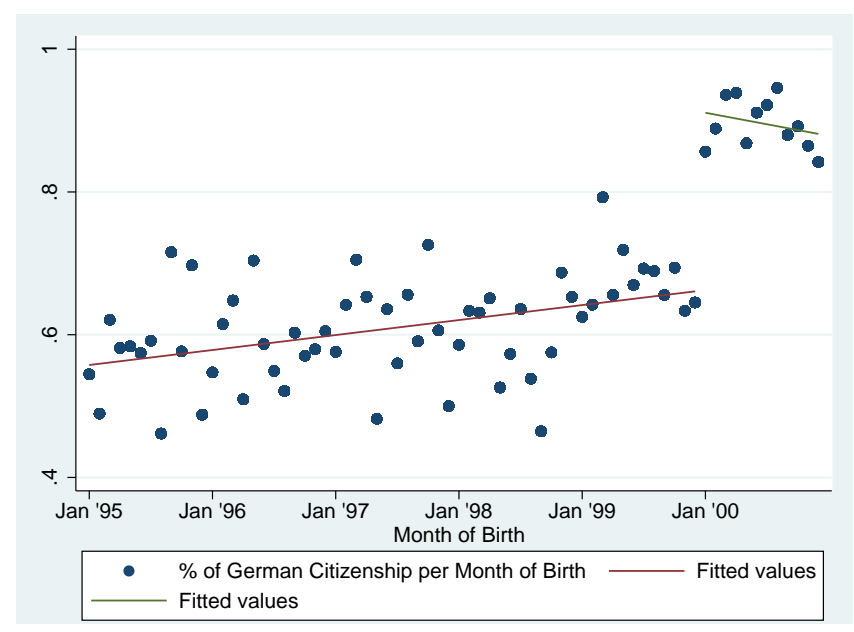

Source: German Micro Census 2009-2012

Figure 3 displays the share of children enjoying German citizenship among the children whose parents had not yet resided for eight years in Germany at the time of child birth. Clearly, there is no jump in citizenship around the cut-off date set by the reform of the German naturalization law, but a smooth upward trend in the share of children enjoying German citizenship. Hence, we feel comfortable to conclude that the jump in citizenship displayed in the previous Figures A.1 and 2 is related to the introduction of birthright citizenship. 
Figure 3: \% of Citizenship by Month of Birth - Parents residing less than 8 years in Germany

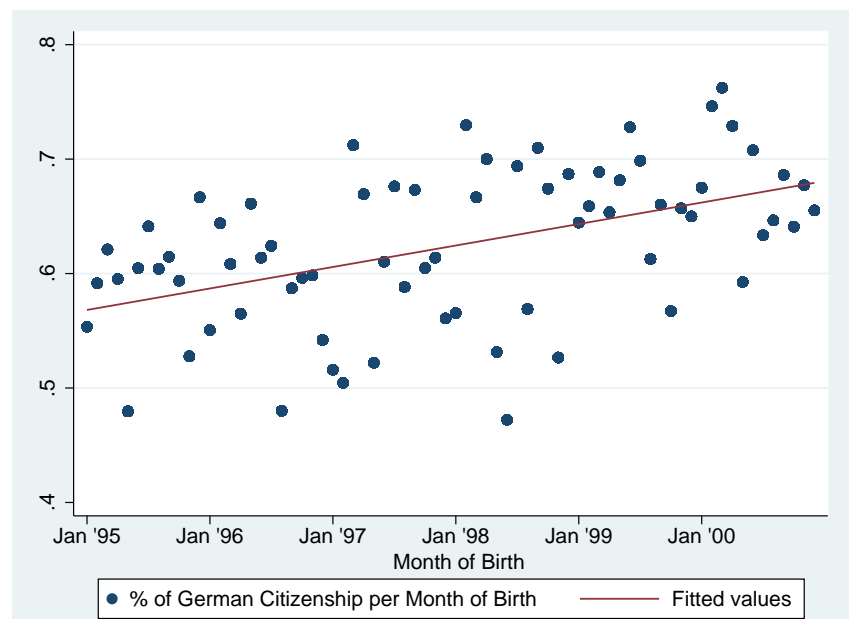

Source: German Micro Census 2009-2012

\subsection{Birthright Citizenship and Children's Education}

Do immigrant children gain access to and progress better in the educational system due to the introduction of "ius solis" in Germany in 2000? Table 1 displays the DiD estimates for children's preschool attendance (Panel 1), children's readiness for primary school (Panel 2) and tracking into upper secondary school (Panel 3). The estimates are based on equation 1 using the sample of all immigrant children. The estimates displayed in column (1) stem from a DiD equation controlling for children's age and month of birth only. In further specifications, shown in column (2) and (3), we additionally control for children's characteristics, such as gender and number of siblings, and family characteristics, such as single parenthood and parental education. Results are robust across the three specifications. In turn, we discuss the estimates based on the most parsimonious specification. 
Table 1: Effects on children's educational participation

\begin{tabular}{lccc}
\hline \hline & $(1)$ & $(2)$ & $(3)$ \\
\hline Panel 1: Kindergarten & & & \\
Born after the reform & $0.032^{* *}$ & $0.032^{* * *}$ & $0.032^{* *}$ \\
& $(0.013)$ & $(0.013)$ & $(0.013)$ \\
Adj. $R^{2}$ & 0.002 & 0.002 & 0.014 \\
Baseline level & 0.917 & 0.917 & 0.917 \\
Children & 6752 & 6752 & 6752 \\
& & & \\
Panel 2: School Readiness & & & \\
Born after the reform & -0.006 & -0.006 & -0.012 \\
& $(0.019)$ & $(0.019)$ & $(0.019)$ \\
Adj. $R^{2}$ & 0.026 & 0.026 & 0.049 \\
Baseline level & 0.863 & 0.863 & 0.863 \\
Children & 6716 & 6716 & 6716 \\
& & & \\
Panel 3: Upper secondary school & & & \\
Born after the reform & $0.073^{* *}$ & $0.063^{*}$ & $0.066 *$ \\
& $(0.031)$ & $(0.037)$ & $(0.035)$ \\
$R^{2}$ & 0.0117 & 0.029 & 0.1166 \\
Baseline level & 0.245 & 0.245 & 0.245 \\
Children & 2595 & 2980 & 2980 \\
& & & \\
\hline Age Dummies & yes & yes & yes \\
Child Controls & no & yes & yes \\
Family Controls & no & no \\
\hline \hline
\end{tabular}

Source: German Micro Census 2010-2012 (in the case of upper secondary school) and administrative data/school entry examination 2005-2007; own calculations

Note: Robust standard errors in parentheses; Child controls consist of children's gender and number of siblings; Family controls contain a dummy for single parenthood and a set of dummies indicating parental education; ${ }^{*} \mathrm{p}$ $<0.1 ;{ }^{* *} \mathrm{p}<0.05 ;{ }^{* * *} \mathrm{p}<0.01$

The introduction of birthright citizenship stimulates immigrant children's preschool attendance: after the introduction of birthright citizenship, immigrant children are $3.2 \mathrm{ppt}$ more likely to attend preschool than they were before. Thus, given the initial level of preschool attendance among immigrant children and native children - $91.7 \%$ and $95.0 \%$, respectively - immigrant children are catching up with native children in terms of their preschool attendance. The introduction of birthright citizenship, however, does not help closing the gap between native children and immigrant chil- 
dren in terms of school readiness. While $91.9 \%$ of all native children are ready for primary school at age six, only $86.3 \%$ of all immigrant children are so. This share is basically unchanged after the reform. Yet, we observe again some benefits of the introduction of birthright citizenship later in the educational system. After the reform of the German naturalization law, immigrant children are $7.3 \mathrm{ppt}$ more likely to attend upper secondary school than they were before. When restricting the sample to only eligible children the effects are slightly stronger: entitlement to citizenship at birth increases immigrant children's prevalence to attend upper secondary school by 8.4 ppt. As such, the gap in upper secondary school attendance between immigrant and native children - $26 \%$ and $37.2 \%$, respectively - is substantially reduced.

In sum, the DiD estimates provide evidence for positive effects of introducing birthright citizenship on second generation immigrant children's participation and progress in the German educational system. In particular, gains are visible in terms of attending preschool and being tracked into upper secondary school. Such gains are likely to open doors for later professional success (Dustmann \& Fabbri, 2003; Dustmann, 2004; Bleakley \& Chin, 2004) and thus, potentially for a better integration of immigrants into the host country's society. The fact that we do not observe any impact on immigrant children's school readiness, but then later on children's tracking into upper secondary school may be due to the fact that initial gains in children's skill are augmenting over time and translate into educational success only after some time (Cunha \& Heckman, 2007).

Are there any gains in children's skill development visible at the time of entering primary school and thus after completion of Kindergarten? Do we observe any immediate returns to increased attendance to Kindergarten as well as to potentially increased integration efforts of parents? Table 2 displays the DiD estimates for children's cognitive skills - measured by children's language proficiency - and children's non-cognitive skills - measured by children's socio-behavioral development - when children are about to enter primary school. There are no significant gains in terms of children's language competencies. Yet, the introduction of birthright citizenship seems to have some benefits for immigrant children's socio-behavioral development. In particular, the introduction of birthright citizenship leads to an improvement of immigrant children's emotional stability by $2.2 \mathrm{ppt}$ and conduct by 1.9 ppt. Good conduct is a crucial factor for success in primary school: sitting still, listening to instructions and conducting exercises are crucial for acquiring the skills taught in school. Emotional stability might furthermore help children to ask questions in class and interact with others. 
Table 2: Effects on children's skill development

\begin{tabular}{|c|c|c|c|}
\hline & $(1)$ & $(2)$ & $(3)$ \\
\hline \multicolumn{4}{|l|}{ 1. German language } \\
\hline Born after the reform & $\begin{array}{c}0.012 \\
(0.098)\end{array}$ & $\begin{array}{c}0.012 \\
(0.098)\end{array}$ & $\begin{array}{c}0.034 \\
(0.099)\end{array}$ \\
\hline Baseline Level & 0.606 & 0.606 & 0.606 \\
\hline Adj. $R^{2}$ & 0.008 & 0.008 & 0.010 \\
\hline Children & 446 & 446 & 446 \\
\hline \multicolumn{4}{|c|}{ 2. Socio-behavioral development } \\
\hline Born after the reform & $\begin{array}{c}0.019^{* *} \\
(0.009)\end{array}$ & $\begin{array}{c}0.019^{* *} \\
(0.009)\end{array}$ & $\begin{array}{c}0.018^{* *} \\
(0.009)\end{array}$ \\
\hline Adj. $R^{2}$ & 0.003 & 0.003 & 0.014 \\
\hline Baseline Level & 0.967 & 0.967 & 0.967 \\
\hline Children & 6268 & 6268 & 6268 \\
\hline \multicolumn{4}{|l|}{ B. Emotional skills } \\
\hline Born after the reform & $\begin{array}{c}0.022^{* *} \\
(0.010)\end{array}$ & $\begin{array}{c}0.022^{* *} \\
(0.010)\end{array}$ & $\begin{array}{c}0.021^{* *} \\
(0.010)\end{array}$ \\
\hline Adj. $R^{2}$ & 0.004 & 0.004 & 0.008 \\
\hline Baseline Level & 0.956 & 0.956 & 0.956 \\
\hline Children & 6473 & 6473 & 6473 \\
\hline \multicolumn{4}{|l|}{ C. Social skills } \\
\hline Born after the reform & $\begin{array}{c}0.001 \\
(0.008)\end{array}$ & $\begin{array}{c}0.001 \\
(0.008)\end{array}$ & $\begin{array}{c}0.000 \\
(0.008)\end{array}$ \\
\hline Adj. $R^{2}$ & 0.002 & 0.002 & 0.004 \\
\hline Baseline Level & 0.974 & 0.956 & 0.956 \\
\hline Children & 5177 & 5177 & 5177 \\
\hline \multicolumn{4}{|l|}{ D.Peer relations } \\
\hline Born after the reform & $\begin{array}{c}-0.003 \\
(0.009)\end{array}$ & $\begin{array}{c}-0.003 \\
(0.009)\end{array}$ & $\begin{array}{c}-0.003 \\
(0.009)\end{array}$ \\
\hline Adj. $R^{2}$ & 0.010 & 0.010 & 0.015 \\
\hline Baseline Level & 0.962 & 0.962 & 0.962 \\
\hline Children & 5177 & 5177 & 5177 \\
\hline Age Dummies & yes & yes & yes \\
\hline Child Controls & no & yes & yes \\
\hline Family Controls & no & no & yes \\
\hline
\end{tabular}

Source: Administrative data/School entrance examination 2005-2007; own calculations

Note: Robust standard errors in parentheses; Child controls consist of children's gender and number of siblings. Family controls consist of single parenthood and a set of dummies indicating parental education; ${ }^{*} \mathrm{p}<0.1 ;{ }^{* *} \mathrm{p}<0.05 ;{ }^{* * *} \mathrm{p}<0.01$ 
Yet, to which extent the observed gains might be due to increased parental integration efforts, due to Kindergarten attendance or due to reduced mobbing or discrimination by peers and local authorities, remains an open question.

\subsection{Robustness}

Can we attribute the effects on immigrant children's educational outcomes presented above solely to the introduction of birthright citizenship? One threat to our identification strategy is the existence of further adjustments in any determinant of children's educational development. To the best of our knowledge, there occurred no further reform around our cut-off date that could have stimulated the educational development of children born in the first half of 2000, while not having affected the educational development of children born in the second half of 1999. Nevertheless, to exclude the possibility of any changes around the cut-off date, we introduce a further control group - native children born between July 1998 and June 2001 - and estimate a triple DiD. ${ }^{16}$ The equation to be estimated looks as follows:

$$
\begin{aligned}
& Y_{i, m}^{s}=\alpha+\beta \text { Treat }_{i}+\gamma \text { After }_{i, m}+\delta \text { After }_{i, m} * \text { Treat }_{i} \\
& + \text { SMigrant }_{i}+\eta \text { M Migrant }_{i} * \text { Treat }_{i}+\theta \text { Migrant }_{i} * \text { After }_{i, m} \\
& + \text { ıMigrant }_{i} * \text { After }_{i, m} * \text { Treat }_{i}+\sum_{m=1}^{12} \kappa_{m} D_{i, m}+\eta X_{i}+\epsilon_{i, n}(2)
\end{aligned}
$$

In comparison to the baseline $\mathrm{DiD}$, the triple $\mathrm{DiD}$ approach controls additionally for the variable Migrant $_{i}$, which indicates whether a child has any migratory background or not. In addition, we interact this variable with Treat $_{i}$, After $_{i, m}$ and After $_{i, m} *$ Treat $_{i}$. The coefficient of interest is thus $\iota$, which measures the change in educational outcomes between immigrant children born shortly before and shortly after the introduction of birthright citizenship, net of not only any general differences between children born in different semesters of a school year, but also net of any differences between children born in different semesters of the school year 1999/2000 unrelated to ethnicity. As we can see in Tables 3 and 4, column (1), the coefficients indicating the impact of the reform on immigrant children's educational out-

\footnotetext{
${ }^{16}$ We only use children whose parents are both born in Germany to keep the control group homogeneous.
} 
comes are basically unchanged. ${ }^{17}$ The introduction of birthright citizenship leads to an increase in immigrant children's preschool attendance by $3.8 \mathrm{ppt}$ and access to upper secondary school by $6.6 \mathrm{ppt}$. The estimated effects on children's emotional stability and conduct are also robust and amount now to $2.1 \mathrm{ppt}$ and $2.3 \mathrm{ppt}$, respectively.

Table 3: Alternative specifications

\begin{tabular}{lcc}
\hline \hline & DiDiD & 4-month window \\
\hline $\begin{array}{l}\text { I. Educational Participation } \\
\text { 1. Kindergarten }\end{array}$ & \\
Born after the reform & $0.038^{* * *}$ & $0.038^{* *}$ \\
& $(0.011)$ & $(0.015)$ \\
Adj. $R^{2}$ & 0.017 & 0.014 \\
Children & 62099 & 4586 \\
& & \\
2. School Readiness & & \\
Born after the reform & -0.010 & -0.000 \\
& $(0.016)$ & $(0.022)$ \\
Adj. $R^{2}$ & 0.060 & 0.038 \\
Children & 62099 & 4586 \\
& & \\
3. Upper Secondary School & & $0.088^{*}$ \\
Born after the reform & $0.066^{*}$ & $(0.046)$ \\
& $(0.041)$ & 0.0102 \\
Adj. $R^{2}$ & 0.013 & 1713 \\
Children & 15905 & yes \\
& & no \\
\hline Age Dummies & yes & no \\
Child Controls & no & \\
Family Controls & & \\
\hline \hline
\end{tabular}

Sources: Micro Census Data 2010-2012 and Administrative data/School entrance examination 2005-2007; own calculations Note: Robust standard errors in parentheses; Child controls consist of children's gender and the presence of siblings. Family controls contain single parenthood and parental education; ${ }^{*} \mathrm{p}<0.1$; $* * \mathrm{p}<0.05 ; * * * \mathrm{p}<0.01$

\footnotetext{
${ }^{17}$ Robustness of the results for children's language skills can not be tested as language competence is only tested for immigrant children.
} 
Table 4: Alternative specifications

\begin{tabular}{|c|c|c|}
\hline & DiDiD & 4-month window \\
\hline \multicolumn{3}{|c|}{ II. Educational Success } \\
\hline Born after the reform & $\begin{array}{l}- \\
-\end{array}$ & $\begin{array}{c}0.000 \\
(0.123)\end{array}$ \\
\hline Adj. $R^{2}$ & - & -0.002 \\
\hline Children & - & 308 \\
\hline \multicolumn{3}{|c|}{$\begin{array}{l}\text { 2. Socio-behavioral development } \\
\text { A. Conduct/behavior }\end{array}$} \\
\hline Born after the reform & $\begin{array}{l}0.021^{*} \\
(0.011)\end{array}$ & $\begin{array}{l}0.019^{*} \\
(0.011)\end{array}$ \\
\hline Adj. $R^{2}$ & 0.014 & 0.014 \\
\hline Children & 53644 & 4262 \\
\hline \multicolumn{3}{|l|}{ B. Emotional skills } \\
\hline Born after the reform & $\begin{array}{c}0.023^{* *} \\
(0.011)\end{array}$ & $\begin{array}{c}0.030^{* *} \\
(0.012)\end{array}$ \\
\hline Adj. $R^{2}$ & 0.008 & 0.010 \\
\hline Children & 57433 & 4401 \\
\hline \multicolumn{3}{|l|}{ C. Social skills } \\
\hline Born after the reform & $\begin{array}{c}0.001 \\
(0.010)\end{array}$ & $\begin{array}{c}0.003 \\
(0.009)\end{array}$ \\
\hline Adj. $R^{2}$ & 0.013 & 0.004 \\
\hline Children & 44733 & 5177 \\
\hline \multicolumn{3}{|l|}{ D.Peer relations } \\
\hline Born after the reform & $\begin{array}{c}0.000 \\
(0.008)\end{array}$ & $\begin{array}{l}-0.002 \\
(0.011)\end{array}$ \\
\hline Adj. $R^{2}$ & 0.010 & 0.020 \\
\hline Children & 44733 & 5177 \\
\hline Age Dummies & yes & yes \\
\hline Child Controls & no & no \\
\hline Family Controls & no & no \\
\hline
\end{tabular}

Sources: Administrative data/School entrance examination 2005-2007; own calculations

Note: Robust standard errors in parentheses; Child controls consist of children's gender and the presence of siblings. Family controls contain single parenthood and parental education; ${ }^{*} \mathrm{p}<0.1 ;{ }^{*} \mathrm{p}<0.05$; $* * * \mathrm{p}<0.01$ 
Finally, we want to exclude the possibility that parents adjusted their fertility behavior once the new naturalization law was ratified in July 1999. We therefore restrict our sample to children conceived exclusively before the ratification of the reform and thus narrow our sample to birth months closer around the cut-off date. In particular, we restrict the sample to children born four months around the cut-off date (September until April). Results based on the restricted sample are robust (see Tables 3 and 4, column (2)): immigrant children's preschool attendance rises by $3.8 \mathrm{ppt}$, access to upper secondary school by $8.8 \mathrm{ppt}$, conduct by $1.9 \mathrm{ppt}$ and emotional stability by $3.0 \mathrm{ppt}$.

\section{Conclusion}

This study is the first to shed light on the impact of granting birthright citizenship on immigrant children's educational development. Identification is based on the introduction of birthright citizenship in Germany in 2000. Drawing upon two large and comprehensive datasets - school entry examinations for one German state and the German Micro Census - allows us to employ a difference-in-difference approach that compares immigrant children born shortly before and after the cut-off date in the year of policy change and children born shortly before and after the cut-off date in years when no policy change occurred. Our results reveal large gains in terms of children's preschool attendance (by $3.2 \mathrm{ppt}$ ), access to upper secondary school (by 7.3 ppt), children's conduct (by 1.9 ppt) and socio-emotional stability (by 2.2 ppt).

Granting birthright citizenship thus seems to be one promising policy to foster the integration of immigrants into the host country's society. Besides parents' integration efforts (Sajons, 2012; Avitable et al., in press-b), secondgeneration immigrant children gain access to the host country's educational system not only earlier, but also to the most advanced school track, which opens doors for higher education as well as professional success (Dustmann, 2004; Bleakley \& Chin, 2004). Our study therefore should serve as a useful guideline for the current discussion on reforming immigration laws in Western countries. 


\section{References}

Algan, Y., Dustmann, C., Glitz, A., \& Manning, A. (2010). The Economic Situation of First- and Second-Generation Immigrants in France, Germany, and the UK. Economic Journal, 120(542), F4-F30.

Avitable, C., Clots-Figueras, I., \& Masella, P. (in press-a). Citizenship, Fertility and Parental Investment. American Economic Journal: Applied Economics.

Avitable, C., Clots-Figueras, I., \& Masella, P. (in press-b). The Effect of Birthright Citizenship on Parental Integration Outcomes. Journal of Law and Economics.

Becker, B. (2006). Der Einfluss des Kindergartens als Kontext zum Erwerb der deutschen Sprache bei Migrantenkindern. Zeitschrift für Soziologie, 35(6).

Becker, G. S., \& Tomes, N. (1976). Child Endowments and the Quantity and Quality of Children. The Journal of Political Economy, 84(4).

Becker, R., \& Tremel, P. (2011). Bildungseffekte vorschulischer Betreuung, Erziehung und Bildung für Migranten im deutschen Schulsystem. Integration durch Bildung.

Bildungsberichterstattung, A. (Ed.). (2012). Bildung in Deutschland; Ein indikatorengestützter Bericht mit einer Analyse zur kulturellen Bildung im Lebenslauf. Bielefeld: W. Bertelsmann Verlag.

Bleakley, H., \& Chin, A. (2004). Language Skills and Earnings: Evidence from Childhood Immigrants. The Review of Economics and Statistics, 113, 209-230.

Borjas, G. (1985). Assimilation, changes in cohort quality, and the earnings of immigrants. Journal of Labour Economics Vol.3 Nr. 4.

Brantsberg, B., Ragan, J. F., \& Nasir, Z. M. (2002). The Effect of Naturalization on Wage Growth: A Panel Study of Young Male Immigrants. Journal of Labour Economics, 20(3).

Buckles, K., \& Hungerman, D. (2013). Season of Birth and Later Outcomes : Old Question, new Answers. Review of Economics and Statistics, 95(3), 711-724.

Bundesministerium der Justiz und für Verbraucherschutz. (1999). Staatsbürgerschaftsgesetz . Retrieved 16/08/2014, from http://www .gesetze-im-internet.de/rustag/_-_.html

Bundesministerium für Familie, Senioren, Frauen und Jugend. (2013). Familienwegweiser-Kinderbetreuung: Betreuung für Kinder im Alter von drei Jahren bis Schuleintritt. Retrieved 
29/08/2013, from http://www.familien-wegweiser.de/wegweiser/ stichwortverzeichnis, did=45326.html

Chiswick, B. (1978). The Effect of Americanization on the Earnings of Foreign-born Men. Journal of Political Economy, 86(51).

Chiswick, B. (1980). The earnings of white and coloured male immigrants in Britain. Economica, Vol.47, Nr.185.

Cunha, F., \& Heckman, J. (2007). The Technology of Skill Formation. The American Economic Review, 97(2), 31-47.

Danzer, N., \& Lavy, V. (2013, September). Parental Leave and Children's Schooling Outcomes: Quasi-Experimental Evidence from a Large Parental Leave Reform. NBER Working Paper No. 19452.

Duflo, E., Dupas, P., \& Kremer, M. (2011). Peer Effects, Teacher Incentives, and the Impact of Tracking: Evidence from a Randomized Evaluation in Kenya. American Economic Review, 101 (5), 1739-74.

Dustmann, C. (2004). Parental background, secondary school track choice, and wages. Oxford Economic Papers, 56, 209-230.

Dustmann, C., \& Fabbri, F. (2003). Language Proficiency and Labour Market Performance of Immigrants in the UK. The Economic Journal, 113, 209-230.

Dustmann, C., Frattini, T., \& Lanzara, G. (2012). Educational Achievement of Second Generation Immigrants; an international comparison. Economic Policy, 69(27), 143-185.

Dustmann, C., Puhani, P., \& Schönberg, U. (2014). The Long-Term Effects of Early Track Choice. IZA Discussion Paper No.7897.

Dustmann, C., Raute, A., \& Schönberg, U. (2013). Does Universal Child Care Matter? Evidence from a Large Expansion in Pre-School Education. (Draft)

Dustmann, C., \& Schönberg, U. (2012). Expansions in maternity leave coverage and children's long-term outcomes. American Economic Journal: Applied Economics.

Federal Statistical Office . (2012). Press release 314/12. Retrieved 29/08/2013, from https://www.destatis.de/DE/PresseService/ Presse/Pressemitteilungen/2012/09/PD12_314_217pdf .pdf?_ blob=publicationFile

Fougère, D., \& Safi, M. (2009). The Effects of Naturalization on Immigrants' Employment Probability (France, 1968-1999). International Journal of Manpower, 30(1-2), 83-96.

Gathmann, C., \& Keller, N. (2014). Returns to Citizenship? Evidence from Germany's Recent Immigration Reforms. CESifo Working Paper Series No. 4738.. 
Goodman, R. N. (1997). The Strengths and Difficulties Questionnaire: A Research Note. Journal of Child Psychology and Psychiatry(38), 581-586.

Lalive, R., \& Zweimüller, J. (2009). How does parental leave affect fertility and return to work? evidence from two natural experiments. The Quarterly Journal of Economics.

Lüdemann, E., \& Schwerdt, G. (2013). Migration Background and Educational Tracking: Is there a Double Disadvantage for Second-Generation Immigrants? Journal of Population Economics, 26(2).

Piracha, M., \& Zhu, Y. (2012). Precautionary savings by natives and immigrants in Germany. Applied Economics, $44(21)$.

Riphahn, R. T. (2003). Cohort Effects in the Educational Attainment of Second Generation Immigrants in Germany: An Analysis of Census Data. Journal of Population Economics, 16(4), 711-738.

Sajons, C. (2010). Does Granting Citizenship to Immigrant Children Affect Family Return Migration? (Draft)

Sajons, C. (2012). Does immigrant's integration behavior change when their children are born with the host-country citizenship? (Draft)

Schönberg, U., \& Ludsteck, J. (2011). Expansions in maternity leave coverage and mothers' labour market outcomes after childbirth. Working Paper, University College London.

Ständigen Konferenz der Kultusminister der Länder in der Bundesrepublik Deutschland. (2010). Übergang von der Grundschule in Schulen des Sekundarbereichs I . Retrieved 29.08.2013, from http://www.kmk .org/fileadmin/veroeffentlichungen_beschluesse/2010/2010 _10_18-Uebergang-Grundschule-S_eI1-Orientierungsstufe.pdf

Steinhardt, M. F. (2012). Does citizenship matter? The economic impact of naturalizations in Germany. Labour Economics, 19(6), 813-823. 


\section{A Appendix}

Figure A.1: Share of all Second Generation Immigrant Children Enjoying Citizenship by Month of Birth

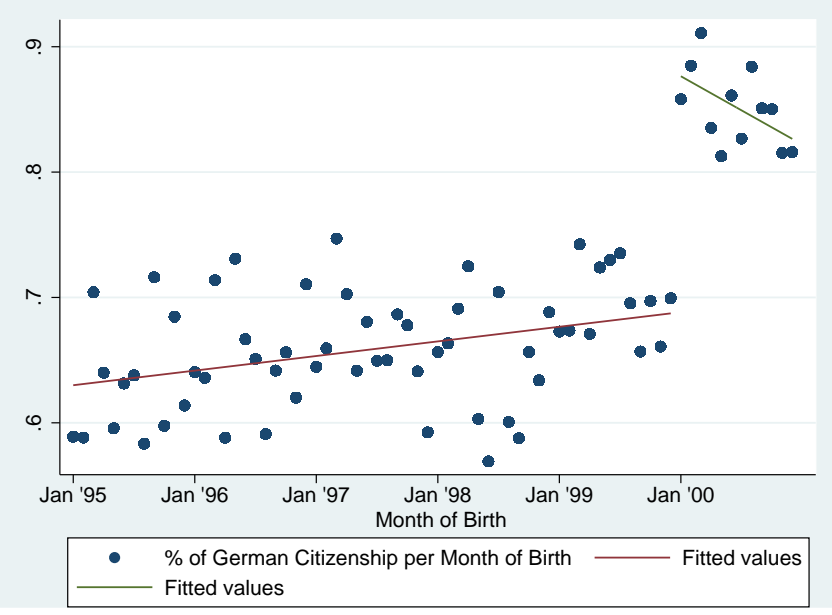

Source: German Micro Census 2009-2012

Table A.1: Descriptives of Outcomes

\begin{tabular}{lccccc}
\hline \hline & All & Born 1999 & Born 2000 & Diff & p-Value \\
\hline Panel A: Competencies & & & & & \\
German knowledge & .614 & .606 & .619 & .013 & $(.859)$ \\
Conduct/Behavior & .967 & .967 & .967 & .00 & $(.959)$ \\
Emotional Skills & .958 & .956 & .959 & .004 & $(.652)$ \\
Social Skills & .974 & .974 & .974 & .000 & $(.992)$ \\
Peer relations & .959 & .962 & .956 & -.006 & $(.539)$ \\
Panel B: Integration & & & & & \\
Kindergarten Attendance & .93 & .917 & .942 & .025 & $(.019)$ \\
On-time School Recommendation & .814 & .863 & .772 & -.091 & $(.000)$ \\
Gymnasium Attendance & .264 & .245 & .282 & .037 & $(.36)$ \\
Panel C: Treatment & & & & & \\
Citizenship & .797 & .674 & .914 & .24 & $(.000)$ \\
\hline \hline
\end{tabular}

